\title{
Fides et Labor: A Student's View of the Motivation to Learn and Live
}

\author{
Ben Gardner, BA \\ Park University
}

In exploring the fundamental principles that have guided and sustained my own motivation as a Park student, I find that there are two-often "ivory-tower"perspectives on the issue of motivation.

One perspective calls for highly motivated individuals who are committed to obtaining their education. Whether enrolled at Princeton, Park, or Podunk U., these individuals will make the best of what educational opportunities they are given. Teachers thus occupy a hugely stereotypical role in education, mainly as dispensers of facts. The other perspective places the responsibility for motivation squarely on the shoulders of the teacher. Teachers, then, are expected to create each and every condition necessary for learning, to the extent of directing and shaping students' minds, as if students cannot have an independent existence. The failure or success of instructors in this endeavor is generally measured by student performance on standardized tests.

Somewhere between these two perspectives there exists the reality, evidenced throughout my student experience, that even the most determined student will not be unaffected by a teacher's apathy. By the same token, time and again I have seen a teacher's irresistible motivation bring the most uncaring of students to learn-often against these students' own prejudices. Motivation, in these instances, is a powerful, symbiotic force.
By the same token, time and again I have seen a teacher's irresistible motivation bring the most uncaring of students to learn-often against these students' own prejudices.

Given the positive influence of motivation, the single greatest tragedy of my time at college, in my perception, has been that, inevitably, there will be a number of teachers, and a much larger body of students, who remain perpetually, even militantly, unmotivated, forever expecting the passion for learning and growth to be brought to the classroom by the other party.

As I look back on my years at Park, there have been a number of things that have served to motivate me. I would like to share them with you, as different aspects of student motivation.

First, the expectation of one's personal best is a powerful motivator. Beginning in my freshman year with such masterful teachers as Dr. Andrew Johnson, Dr. Andrew Klein, and Dr. Jeff Glauner, and stretching through to this senior year with Dr. Lolly Ockerstrom, I have been appreciative when my classroom work and assignments have often been handed back to me with a grade that expressed disapproval, yet with the comment that "I've seen what you can do, and this falls short of that potential." Such honest assessment has driven me to reach higher and try harder, both in discovering my capabilities, and in perfecting my grasp of those matters to which I had applied myself. In those inevitable moments of self-doubt and discouragement that come as a result of fatigue, stress, and conflict, such expectations and the high praise they carry, serve as strong bulwarks against the poisons of depression and defeatism.

Second, preparation on the teacher's part is an effective motivational tool for encouraging learning. As much of a drudgery as the task may be, I would encourage instructors never to underestimate the power of pre-class preparation Nobody doubts the expertise of Park's faculty; but authority alone, in the various academic fields represented at Park, is in my perspective hardly a guarantee of effective, educational leadership. One of the first skills that I developed here at Park 
was the ability to perceive which of my teachers had spent time beforehand plotting a course for the class and developing strategies and rubrics for learning, and which of them tended to stop by their offices ten minutes before class to print off a handful of diagrams and grab the textbook from the shelf. The constant atmosphere of objective, substantive learning in Dr. Dennis Okerstrom's classes, and the lively give-and-take in Dr. Carolyn Anderson's algebra classes, well demonstrate the motivation that prepared leadership fosters.

Thirdly, a source of motivation for me has consistently been the personal accessibility and sincerity of my teachers. Whether it be Dr. Don Williams discussing poetry after a chance meeting outside McKay Hall, Dr. Tim Gabor reviewing deer season with me in the school cafeteria, or Prof. Cynthia Williams hosting an ice-cream social at home, the teachers who have motivated me the most have consistently carried their love of teaching into circles far beyond the limited scope of our classroom interaction. Their respect for me, and their insistence that I apply myself to the full, are not limited to the classroom, but involve my whole person in just about every aspect of my life. In taking up the theme of personal development outside of the classroom, in doing their best to foster learning outside of their salaried functions, these instructors have encouraged me to learn and develop in the world at large. I am and will forever be grateful for those teachers who have contributed to my education at all levels. For this, I am all the richer for.

Fourthly, an important feature of student motivation is the subject matter's relevance to the real world. Given that by its very nature, teaching is often hands-off and hypothetical, it is only a small step from listening to such abstract matters being discussed by the instructor, to learning these, taking an equally distant, and increasingly uninterested perspective.

Dr. Steve Atkinson's stories from his own professional career, woven throughout his class presentations; Prof. Machrina Blasdell's constant touchstones from her own ministries and experiences; and Dr. Doug Burn's anecdotes from his time in a research lab, all contribute to a perspective of their teaching as useful, immediately applicable, and profoundly relevant to life and experience.

Anecdotes and storytelling not only cast

the learning experience in a much more realistic light, but they also serve to enhance a student's realization that, no matter what our position in life, we are all human. Many of the more ivorytower concepts inherent to the various disciplines, so well represented at Park, tend to focus our attention on cold arguments and disembodied principles. Too often, we students have allowed ourselves to believe that academic

Anecdotes and storytelling not only cast the learning experience in a much more realistic light, but they also serve to enhance a student's realization that, no matter what our position in life, we are all human.

success must come at the price of careful detachment from the real world. Those teachers who have shared their trials and triumphs with us daily, motivate us to embrace life- in our studies and elsewhere.

These four aspects of motivation involving the expectations, pre-class preparation, and accessibility of my professors, and the relevance of their teaching, have served as powerful sources of encouragement and inspiration throughout my time here at Park. I am proud to say that Park's faculty represents the best of what multitudes of incoming freshmen will realize has been one of the more outstanding features of their education.

A fifth and final aspect of student motivation that I would like to share with you relates to our Park motto, Fides et Labor: faith and work.

This "faith", as George S. Park and his fellows envisioned it, carries decidedly religious and evangelistic overtones. As a conservative evangelical cut from a similar theological cloth, I can relate to the intrinsic motivation of honoring Christ. In His perfection lie the reason and foundational motivation for all that I do. Through my interaction with many of my teachers and classmates at Park, I have come to understand that faith is a powerful, motivating force in their lives as well. 
Whether or not this more traditional interpretation of faith is accepted on all sides, I believe that there is unity in the understanding [that faith can also represent our hopes, aspirations, and motivations: our beliefs relating to the worthiness of what should be done, and how this plays into our hopes for a better future.

Yet merely hoping for, merely believing in, a better future is not enough. As the Apostle James would tell us, "Faith without works is nothing." Thus the importance of labor; work is necessary for the ultimate realization of all to which we aspire and for which we hope.

Fides et Labor has been a powerful, motivating force in my own life. In coming to Park, I have been honored to take my place among the ranks of those students and faculty members who are daily committed to making this campus-this state, our nation, and this world-a better place.

It is grueling to labor alone, even at such worthy tasks. If isolated, even the noblest of hopes and expectations tend to wither and lose their vibrancy. Thus, one of the most powerful motivations that I have experienced here is the quiet courage and determination that each of my teachers have exemplified, in and outside the classroom, to make my life and the lives of

Thus, one of the most powerful motivations that I have experienced here is the quiet courage and determination that each of my teachers have exemplified, in and outside the classroom, to make my life and the lives of so many others more fruitful.

so many others more fruitful. In the fraternity of this shared vision of hope for good, and the shared effort to diligently realize this hope, I have found the strength and motivation to persevere and achieve.

I am certain that of all that Park's faculty and staff have given me over these years of my college experience, their hopes and commitment to labor, will continue to motivate and inspire me in all that I do, and long after time has dulled the edges of the education I have received here at Park.

Gardner is a graduate of the English department at Park University. He was born in Brazil, South America, where his parents are Baptist missionaries. He spent 15 years in South and Central America, and has been living in Kansas City since 2001. Gardner intends to return to South America after graduate school to carry on his parents' ministries as they relate to church-planting, social work in orphanages and other contexts of social need. 